\title{
Estimating the Thickness of Sedimentation within Lower Benue Basin and Upper Anambra Basin, Nigeria, Using Both Spectral Depth Determination and Source Parameter Imaging
}

\author{
Adetona A. Abbass ${ }^{1}$ and Abu Mallam ${ }^{1,2}$ \\ ${ }^{1}$ Department of Physics, Federal University of Technology P.M.B. 65 Minna, Niger State, Nigeria \\ ${ }^{2}$ Department of Physics, University of Abuja, P.M.B. 117Abuja, Nigeria
}

Correspondence should be addressed to Abu Mallam; mallamabu@yahoo.com

Received 31 March 2013; Accepted 22 April 2013

Academic Editors: A. Donnellan and S. Pullammanappallil

Copyright (c) 2013 A. A. Abbass and A. Mallam. This is an open access article distributed under the Creative Commons Attribution License, which permits unrestricted use, distribution, and reproduction in any medium, provided the original work is properly cited.

\begin{abstract}
The Total Aeromagnetic Data covering the study area was subjected to First Vertical Derivative, Spectral Depth Analysis, and Source Parameter Imaging (SPI). The result from the First Vertical Derivative shows that the Northern part of the area is covered by the young biotite granite of Precambrian origin, and the western edge is covered by the old granite, gneisses, and migmatite of Western Nigeria, while the remaining area is covered by the cretaceous sedimentary deposits. The entire area was divided into forty-eight sections. Spectral Depth Analysis was run for each of these forty-eight sections; the result shows that a maximum depth above $7 \mathrm{~km}$ was obtained within the cretaceous sediments of Idah, Ankpa, and below Udegi at the middle of the study area. Minimum depth estimates between 188.0 and 452 meters were observed around the basement regions. Results from Source Parameter Imaging show a minimum depth of 76.983 meters and a maximum thickness of sedimentation of $9.847 \mathrm{~km}$, which also occur within Idah, Ankpa, and Udegi axis. The disparity observed in depth obtained by each method is discussed based on the merit and demerit of each method, and the depths obtained were compared with results from previous researchers. Geophysical implication of the result to oil and gas exploration in the area is briefly discussed.
\end{abstract}

\section{Introduction}

Of all the magnetic minerals that occur in nature, magnetite is the most abundant. Aeromagnetic surveys reflect almost exclusively the distribution of magnetite and pyrrhotite in rocks. On a global basis, the others can probably be ignored [1, 2]. Thus aeromagnetic surveys, in particular terms, map the magnetite in the rocks below the aircraft. While aeromagnetic surveys are extensively used as reconnaissance tools, there has been an increasing recognition of their value for evaluating prospective areas by virtue of the unique information they provide. Outline of the roles of aeromagnetic survey is as follows [3].

(i) Delineation of volcano-sedimentary belts under sand or other recent cover, or in strongly metamorphosed terrains when recent lithologies are otherwise unrecognizable. (ii) Recognition and interpretation of faulting, shearing, and fracturing not only as potential hosts for a variety of minerals, but also an indirect guide to epigenetic, stress related mineralization in the surrounding rocks.

(iii) Identification and delineation of post-tectonic intrusive. Typical of such targets are zoned syenite or carbonatite complexes, kinerlites, tin-bearing granites, and mafic intrusions.

(iv) Direct detection of deposits of certain iron ores.

(v) In prospecting for oil, aeromagnetic data can give information from which one can determine depths to basement rocks and thus locate and define the extent of sedimentary basins. Sedimentary rocks however exert such a small magnetic effect compared with 


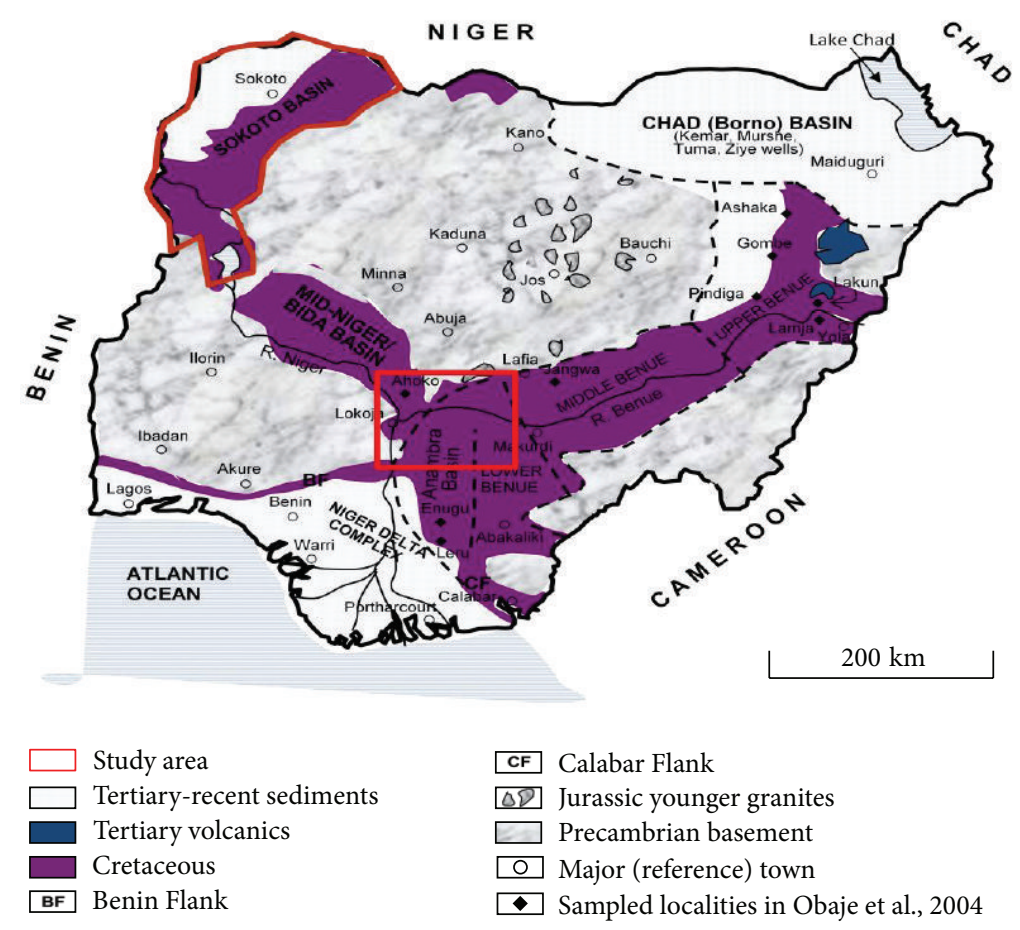

FIGURE 1: Geology map of Nigerian showing the location of the study area.

igneous rocks that virtually all variations in magnetic intensity measurable at the surface result from topographic or lithologic changes associated with the basement or from igneous intrusions [4].

In this paper, a combination of source parameter imaging and Euler deconvolution were employed to evaluate the depth to source magnetic rocks within lower parts of Benue Basin and upper parts of Anambra basin.

\section{Location and Extent of the Study Area}

The study area covers the Lower Benue Trough, the Upper part of Anambra Basin, and the basement complexes bounding it at the West and Northern edges (Figure 1). The area is bounded by Latitude $7.0^{\circ} \mathrm{N}$ to $8.5^{\circ} \mathrm{N}$ and Longitude $6.5^{\circ} \mathrm{E}$ to $8.5^{\circ} \mathrm{E}$. The physiological features recognized in the area are the river Benue, river Anambra, and river Okulu. Twelve aeromagnetic maps covered the study area and are numbered $(227,228,229,230,247,248,249,250,267,268,269$, and 270), a total area of 36,300 square kilometers. The study area touches four states majorly, which are Nassarawa at the upper part, Kogi, Enugu, and Benue States at the lower part (Figure 2).

2.1. Geology of Lower Benue and Upper Anambra Basin. Sedimentation in the Lower Benue Trough commenced with the marine Albian Asu River Group, although some pyroclastics of Aptian-Early Albian ages have been sparingly reported [5]. The Asu River Group in the Lower Benue Trough comprises the shales, limestones, and sandstone lenses of the Abakaliki
Formation in the Abakaliki area and the Mfamosing Limestone in the Calabar Flank [6]. The marine CenomanianTuronian Nkalagu Formation (black shales, limestones, and siltsones) and the interfingering regressive sandstones of the Agala and Agbani Formations rest on the Asu River Group. Mid-Santonian deformation in the Benue Trough displaced the major depositional axis westward which led to the formation of the Anambra Basin. Post-deformational sedimentation in the Lower Benue Trough, therefore, constitutes the Anambra Basin. Sedimentation in the Anambra Basin thus commenced with the Campanian-Maastrichtian marine and paralic shales of the Enugu and Nkporo Formations, overlaid by the coal measures of the Mamu Formation. The fluviodeltaic sandstones of the Ajali and Owelli Formations lie on the Mamu Formation and constitute its lateral equivalents in most places. In the Paleocene, the marine shales of the Imo and Nsukka Formations were deposited, overlain by the tidal Nanka Sandstone of Eocene age. Downdip, towards the Niger Delta, the Akata Shale and the Agbada Formation constitute the Paleogene equivalents of the Anambra Basin (Figure 2). The Basin Formation and the Imo Shale mark the onset of another transgression in the Anambra during the aleocene. The shales contain significant amount of organic matter and may be potential source for the hydrocarbons in the northern part of the Niger Delta [7]. In the Anambra Basin, they are only locally expected to reach maturity levels for hydrocarbon expulsion.

The Enugu and the Nkporo Shales represent the brackish marsh and fossiliferous pro-delta facies of the Late Campanian-Early Maastrichtian depositional cycle [7]. Deposition of the sediments of the Nkporo/Enugu 


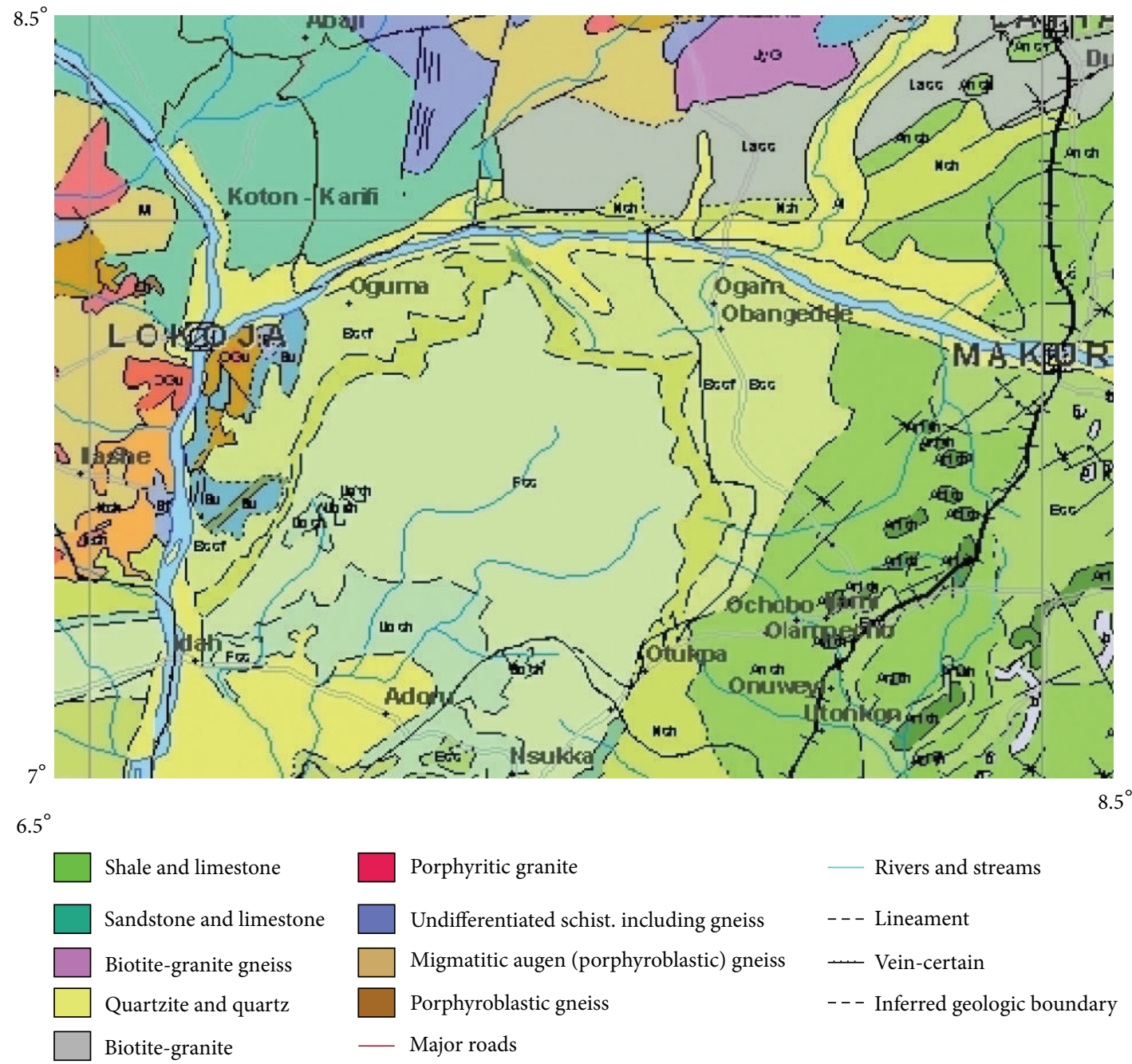

Figure 2: Geology map of the study area (adapted from the Geological and Mineral Map of Nigeria, 2009, Nigerian Geological Survey Agency).

Formations reflects a funnel-shaped shallow marine setting that graded into channeled low-energy marshes. The coal-bearing Mamu Formation and the Ajali Sandstone accumulated during this epoch of overall regression of the Nkporo cycle. The Mamu Formation occurs as a narrow strip trending north-south from the Calabar Flank, swinging west around the Ankpa plateau and terminating at Idah near the River Niger. The best exposure of the Nkporo Shale is at the village of Leru (Lopauku). The Ajali Sandstone marks the height of the regression at a time when the coastline was still concave. The converging littoral drift cells governed the sedimentation and are reflected in the tidal sand waves which are characteristic for the $72 \mathrm{~km}$ south of Enugu on the Enugu-Portharcourt express road, while that of Enugu Shale is at Enugu, near the Onitsha-Road flyover. The Mamu Formation is best exposed at the Miliken Hills in Enugu, with well-preserved secions along the road cuts from the King Petrol Station up the Miliken Hills and at the left bank of River Ekulu near the bridge to Onyeama mine.

\section{Materials and Methods}

The procedures employed in this research include the following.

(1) Production of Total Magnetic Intensity (TMI) map of the study area using MONTAJ software.

(2) Perform vertical derivative of the TMI data to enhance shallow geological features and horizontal derivative to identify geology boundaries in the profile data.

(3) Production of the Geomagnetic Map of the Study Area from Magnetic Signatures and Geology Map.

(4) Spectral depth determination to buried magnetic rocks within the study area.

(5) Depth evaluation using Source Parameter Imaging.

3.1. Source of Aeromagnetic Data. A new dataset has been generated from the largest airborne geophysical survey ever 
undertaking in Nigeria, which is helping to position the country as an exciting destination for explorers. This survey which was conducted in three phases between 2005 and 2010 was partly financed the Nigerian Federal Government and the World Bank as part of a major project known as the Sustainable Management for Mineral Resources Project. All of the airborne geophysical work, data acquisition processing and compilation, was carried out by Fugro Airborne Surveys; the survey acquired both magnetic and radiometric data compilation. The recent survey has a Tie-line spacing of $500 \mathrm{~m}$, flight line spacing of $100 \mathrm{~m}$, and Terrain clearance of $100 \mathrm{~m}$ using TEMPEST system. Compared with the $1970 \mathrm{~s}$ survey which has a Tie-line spacing of $20 \mathrm{~km}$, flight line spacing of $2 \mathrm{~km}$, and flying altitude of $200 \mathrm{~m}$, these levels of survey are intensive and detailed for the objectives of this research. Data covering the twelve aeromagnetic sheets numbered $(227,228,229,230,247,248,249,250,267,268,269$, and 270) was acquired from The Nigerian Geological Survey Agency, 31, Shetima Mangono Crescent Utako District, Garki, Abuja.

3.2. Spectral Depth-Determination Methods. The Fourier transform of the potential filed due to a prismatic body has a broad spectrum whose peak location is a function of the depth to the top and bottom surfaces and whose amplitude is determined by its density or magnetization. You can relate the peak wavenumber $\left(\omega^{\prime}\right)$ to the geometry of the body according to the following expression [8]:

$$
\omega^{\prime}=\frac{\operatorname{lin}\left(h_{b} / h_{t}\right)}{h_{b}-h_{t}} .
$$

$\omega^{\prime}$ is the peak wavenumber in radian or ground-unit, $h_{t}$ is the depth to the top, and $h_{b}$ is the depth to the bottom. For a bottomless prism, the spectrum peak at the zero wavenumber is according to the expression

$$
f(\omega)=e^{-h \omega}
$$

where $\omega$ is the angular wavenumber in radians/ground-unit and $h$ is depth to the top of the prism [9].

When considering a line that is long enough to include many sources, you can use the log spectrum of these data to determine the depth to the top of a statistical ensemble of sources using the relationship

$$
\log E(k)=4 \pi h k
$$

where $h$ is the depth in ground-units and $k$ is the wavenumber in cycles/ground-unit.

You can determine the depth of an "ensemble" of source by measuring the slope of the energy (power) spectrum and dividing by $4 \pi$. A typical energy spectrum for magnetic data may exhibit three parts-a deep source component, a shallow source component, and a noise component.

Figure 9 illustrates the interpretation of an energy spectrum into these three components [8].
3.3. Theory of Source Parameter Imaging. The basics are that for vertical contacts, the peaks of the local wave number define the inverse of depth. In other words,

$$
\text { Depth }=\frac{1}{K_{\max }}=\frac{1}{\left(\sqrt{(\partial \operatorname{Tilt} / \partial x)^{2}}+(\partial \operatorname{Tilt} / \partial y)^{2}\right)_{\max }},
$$

where the Tilt is given as

$$
\begin{aligned}
\text { Tilt } & =\arctan \left(\frac{(\partial T / \partial z)}{\left(\sqrt{(\partial T / \partial x)^{2}}+(\partial T / \partial y)^{2}\right)}\right) \\
& =\arctan \left(\frac{\partial T / \partial z}{\operatorname{HGRAD}}\right)
\end{aligned}
$$

The Source Parameter Imaging (SPI) method calculates source parameters from gridded magnetic data. The method assumes either a 2D sloping contact or a 2D dipping thinsheet model and is based on the complex analytic signal. Solution grids show the edge locations, depths, dips, and susceptibility contrasts. The estimate of the depth is independent of the magnetic inclination, declination, dip, strike, and any remanent magnetization. Image processing of the source-parameter grids enhances detail and provides maps that facilitate interpretation by nonspecialists [10].

Estimation of source parameters can be performed on gridded magnetic data. This has two advantages. First, this eliminates errors caused by survey lines that are not oriented perpendicular to strike. Second, there is no dependence on a user-selected window or operator size, which other techniques like the Naudy [11] and Euler methods require. In addition, grids of the output quantities can be generated, and subsequently image processed to enhance detail and provide structural information that otherwise may not be evident.

\section{Analysis and Results}

4.1. The Total Magnetic Intensity (TMI) Map of the Study Area. The total magnetic intensity map of the study area bounded by $7.0^{\circ}-8.5^{\circ} \mathrm{N}$ latitude and $6.50^{\circ}-8.0^{\circ} \mathrm{E}$ longitude is produced into maps (Figure 4 ) which is in color aggregate. The magnetic intensity of the area ranges from -2415.97 minimum to 1264.72 maximum with an average value of $33.87 \mathrm{nT}$. The total number of data points is $3,667,251$. The area is marked by both high and low magnetic signatures, which could be attributed to several factors such as (1) variation in depth, (2) difference in magnetic susceptibility, (3) difference in lithology, and (4) degree of strike. Subsequent interpretation under qualitative analysis will reveal more information of each. The northern edge and the western edge of the study area are inhibited by short wavelength (high frequency in occurrence) signatures, which are generally attributed to basement areas. These are mostly prominent on sheets (228) Katakwa, (229) Udegi, and (247) Lokoja (Figure 3).

The left part of the northern edge comprised of Koton Karfi, Katakwa, Udegi sheets and part of the western edge of Lokoja sheet shows a lot of activity, as they are dotted 


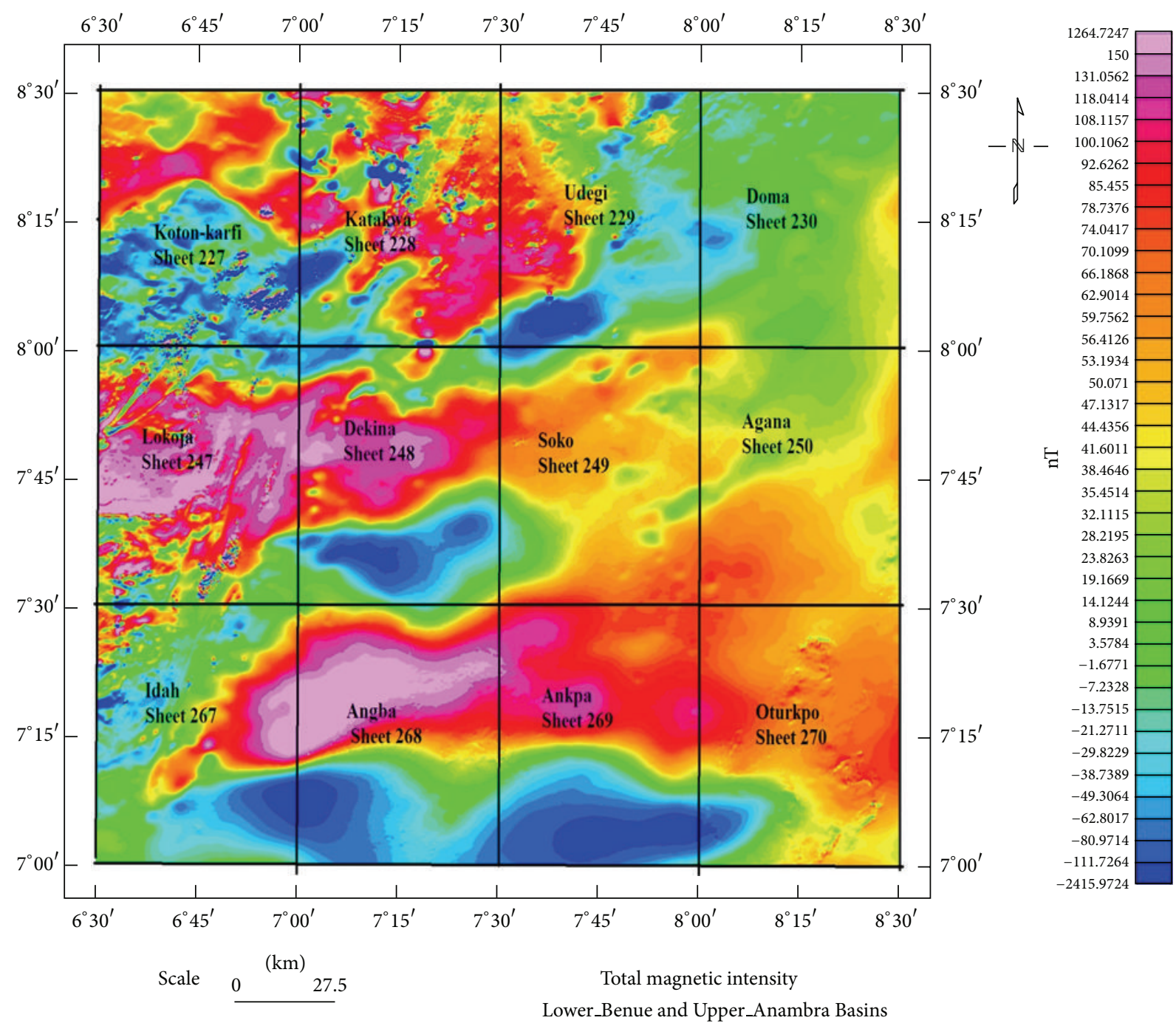

FIgURE 3: Total Magnetic Intensity Map of the study area showing major towns flown over.

by mixtures of both high and low magnetic structures with features that are characteristics of surface to near surface structures such as outcrops.

Structural trends within the study area are N-E and NESW (First Vertical Derivative of the TMI and First Vertical Derivative in Figure 4). High Frequency (short wavelength) signatures observed at the Northern and Western portion of the study area revealed a shallow depth to magnetic source typical of Basement Complex. Long wavelength signatures observed at the major part of the study area are as a result of deep magnetic source typical of Sedimentary basin.

4.2. Interpretation of Geo-Magnetic Map. From the aeromagnetic anomaly map, Figure 3, a geo-magnetic sketch map over the study area, is compiled, which provides a new insight on the lithology of the study area. The geomagnetic sketch Figure 5 inferred from geology Figure 2 and the magnetic susceptibility shows that the basin is covered with the Chhattisgarh sediments with intrusions of granite and greenstone. The striking feature with NW-SE trending maximum negative magnetic anomaly zone in the northern part of basin is associated with Sonakhan greenstone belt Undifferentiated Older granite, mainly porphyritic buried under the sediments. Granite, granitized gneiss, and porphyroblastic granite. Rock type at the Northern portion is identified as Biotite gneiss. False bedded sandstone, coal, sandstone and shale.

Rock type at the western portion of the study area is identified from geology as Undifferentiated Older granite, mainly porphyritic granite granitized gneiss with porphyroblastic granite. Rock type at the Northern portion is identified as Biotite gneiss. False bedded sandstone, coal, sandstone, and shale are the lithologic units at the surface within the sedimentary basin. River Alluvium deposition was identified along the river channel.

4.3. Application of Spectral Depth and Results. The entire study area was divided into forty eight (48) sections, Figure 6, 


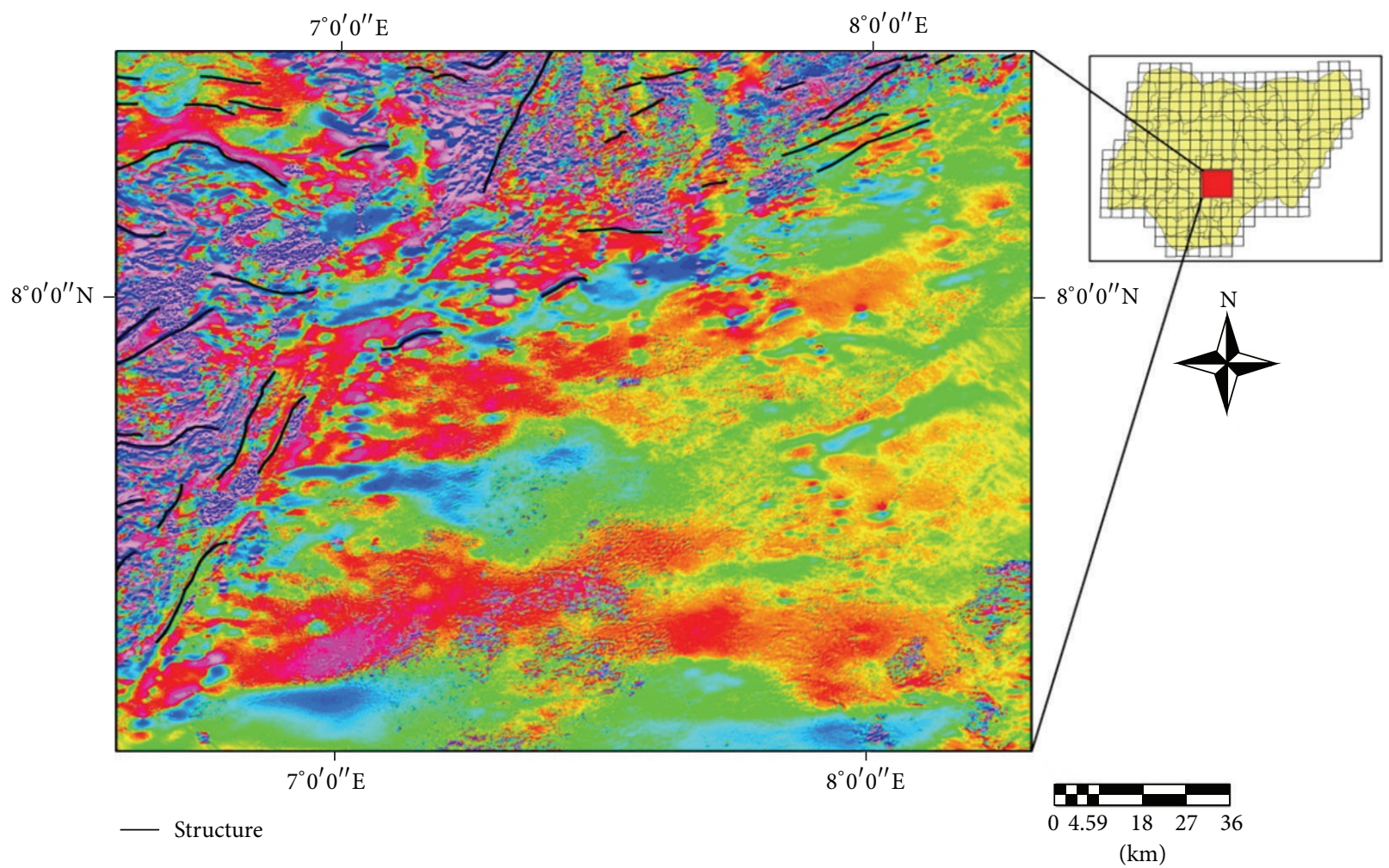

FIgURE 4: First Vertical Derivative Map showing identified structures.

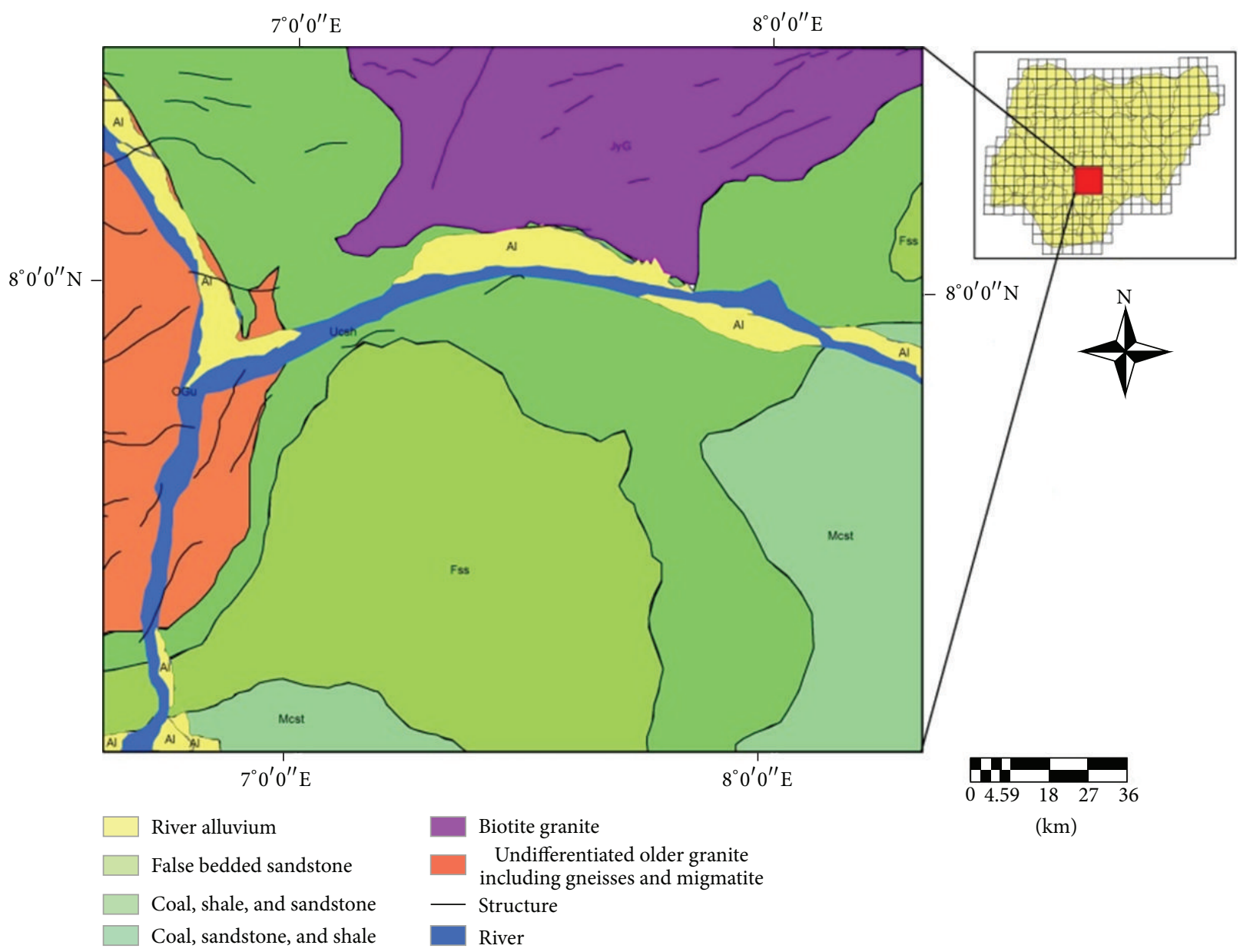

FIGURE 5: Geo-magnetic sketch of the study area produced from geology and magnetic susceptibility. 


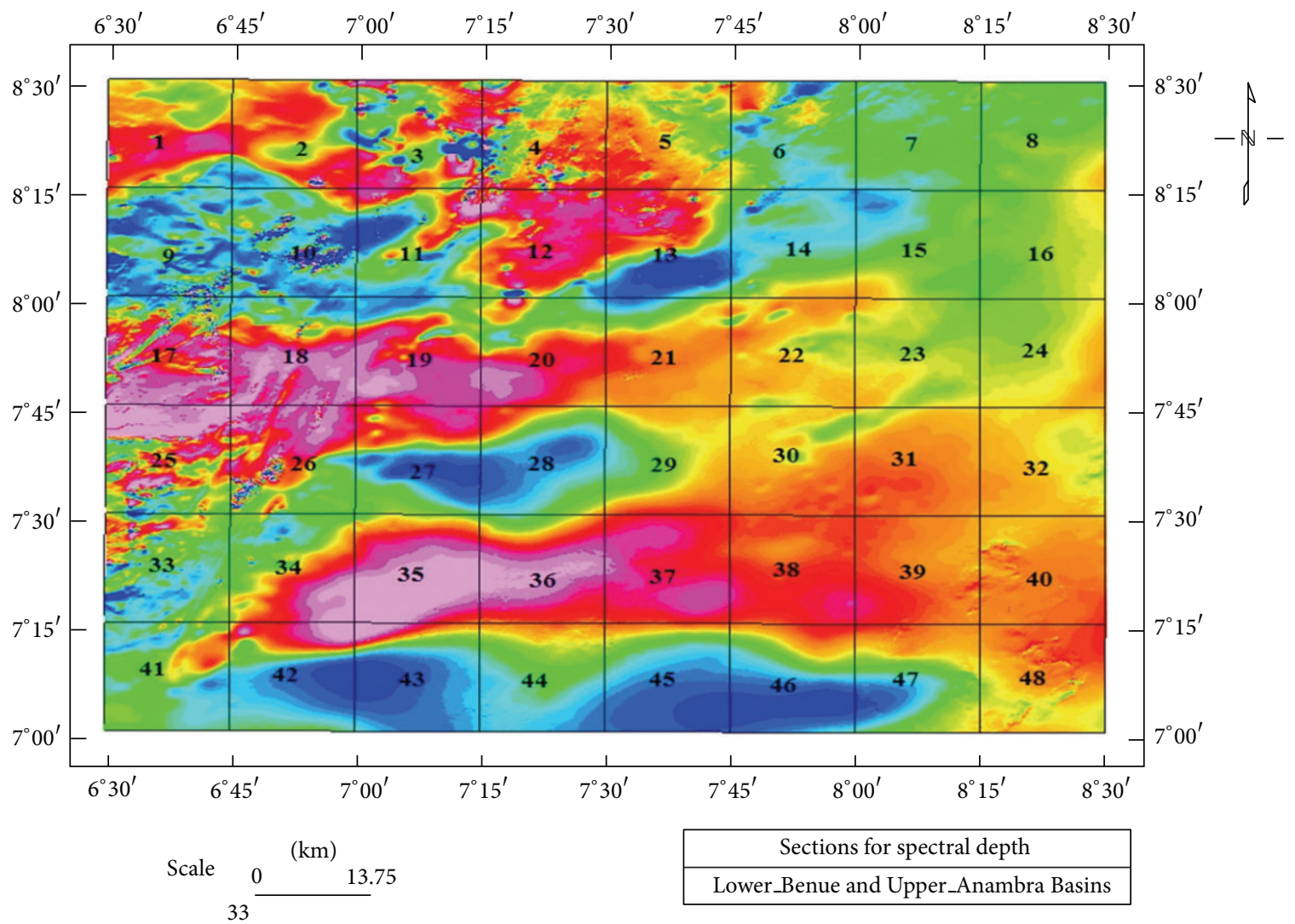

FIGURE 6: TMI Map showing sections for spectral depths of the study area.

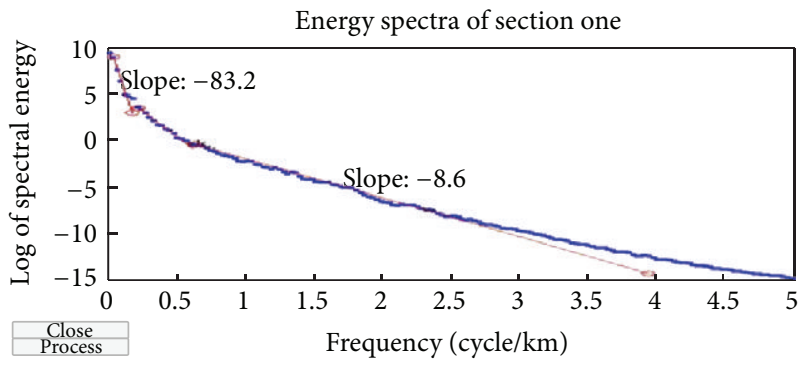

FIGURE 7: Spectral plot of Section One.

and data for each of the forty eight sections. Using the Magmap extension of Oasis Montaj the grid for each section was Fast Fourier transformed and radial average spectrum was run for each section; this produces a column for logs of spectral energy and the corresponding frequencies. These logs of spectral energies were plotted against the corresponding frequencies, and two trend lines were imposed on linear segment, Figure 7 . The gradient of each segment of the straight line was evaluated and converted to depth using the formula $H=\mathrm{GRAD} / 4 \pi$, where $H$ is the expected depth. Two gradients corresponding to the linear segments were evacuated, with the steep gradient related to the deeper sources and the low gradient related to the shallow sources.

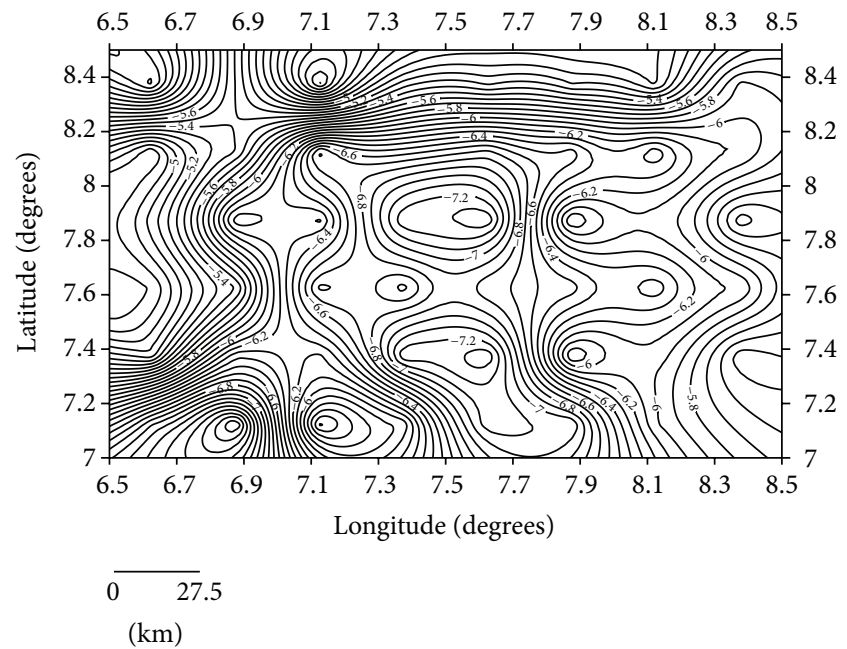

Figure 8: Depths to Basement Contour Map of the study area form Spectral Depth Values.

Results of the spectral analysis of the aeromagnetic data revealed two depth source models.

The first magnetic layer could be attributed to the effect of laterite, ironstone, ferruginous sandstones within and close to the surface. Equally are the effects of surrounding basement 


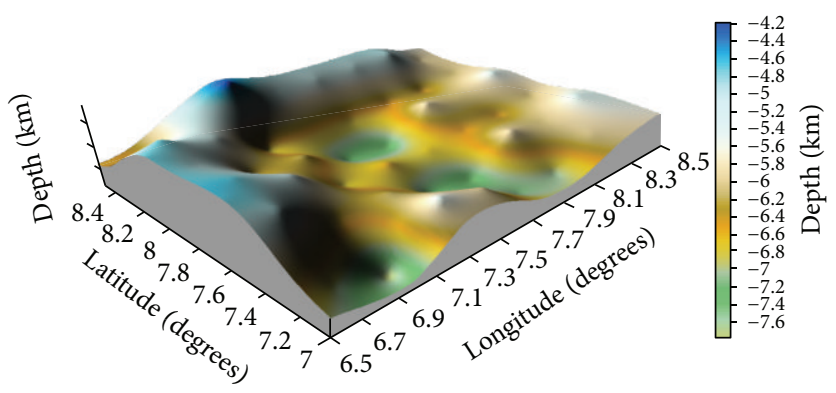

FIgURE 9: 3D construction of the subsurface using Deeper Magnetic Sources Spectral Depth Values.

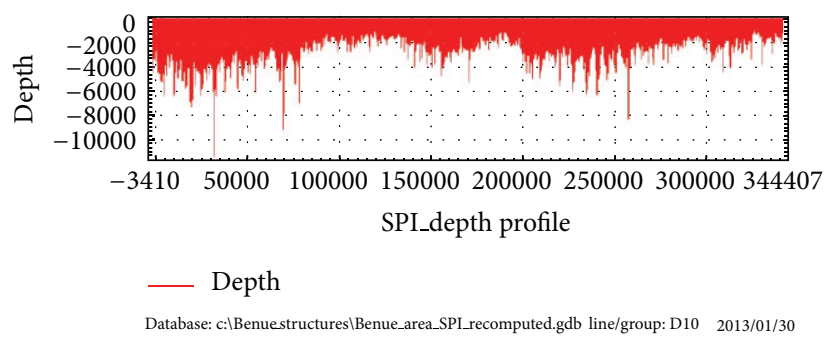

Figure 10: Source Parameter Imaging Depth Profile Map of the study area.

rocks at the Northern and Western flanks of the study area. The shallow magnetic sources depth ranges in depth from 188.0 meters to 452.796 meters with an average value of 313.440 meters (Table 1 ).

The second layer could be attributed to magnetic rocks intrusion into the basement surface, lateral discontinuities in basement susceptibilities, and inter-basement features like faults and fractures. The second layer depth thus represents the depth to basement in the area and this depth has a minimum value of $4.186 \mathrm{~km}$ and maximum of $7.369 \mathrm{~km}$ with average value of $6.013 \mathrm{~km}$.

This represents the average thickness of the sedimentary formation that overlay the basement complex within the lower portion of Benue Basin and the upper portion of Anambra Basin. The deepest parts of the basins are the lower southern edge, these are around Idah, Angba, and Ankpa and the mid-portion of the study area, below Udegi, which record sedimentation above $7 \mathrm{~km}$.

Two maps were produced from the results of the spectral analysis for visual interpretation; these are Figure 8, Depths to Basement Contour Map and Figure 9, 3D construction of the subsurface.

4.4. Application of Source Parameter Imaging and Results. The Source Parameter Imaging (SPI) module from Oasis Montaj software was applied to the TMI data of the study area; the SPI statistics show a minimum depth of 76.983 meters and a maximum depth of 9847.4 meters. Depths to Basement Profile Map (Figure 10) and Depths to Basement Map (in color aggregate) of the study area (Figure 11) show that the deepest part of the basin coincided with those obtained from spectral analysis.

\section{Conclusion}

Spectral Depth Analysis which uses the radial average energy spectrum of an assemblage within a square or rectangular shape area to determine the depth to magnetic source bodies was employed on 48 sections in the study area. With this, spectral depths to magnetic rocks were determined at every $13.75 \mathrm{~km}$ distance across the entire field. Summary of the results shows a maximum depth of $7.36 \mathrm{~km}$ around Idah, Angba, and Ankpa on sheets 267, 268, and 269, respectively; other areas with depth in the range of 6 kilometers are located on sheet 229 Udegi and on sheet 268 Angba.

Source Parameter Imaging was equally applied to evaluate the thickness of sedimentation within the same area and a maximum depth of 9,847 km was obtained.

This depth obtained is higher than that which was arrived at while using Average Radial Spectral Analysis $(7.3 \mathrm{~km})$. The spectral method is not devoid of human error because position of the trend line on the spectral plots which is manually done affects the final result, and most essentially, it has been established that errors in depth estimation increase with depth of source [10].

The result obtained above can be compared to those obtained by other researchers, who have worked around this area; for example, Depth of Sedimentation that ranged from 0.5 to $7 \mathrm{~km}$ was obtained by Ofoegbu in the lower and middle Benue Basin [12]. Likkasson, O. K., equally worked around lower and middle Benue Basin and obtained spectral matching yielding three dipoles equivalent source layers at $0.89 \mathrm{~km}$ to $4.33 \mathrm{~km}$ and $18.22 \mathrm{~km}$, where $4.33 \mathrm{~km}$ corresponds to maximum thickness within middle Benue Basin; research has shown that thickness of sedimentation increases southward within lower Benue Basin [13]. 
TABLE 1: First and second layer depth estimates.

\begin{tabular}{|c|c|c|c|c|c|c|}
\hline SEC_NO & Long & LAT & $\begin{array}{c}\text { Grad. of deeper } \\
\text { sources } \\
\end{array}$ & $\begin{array}{c}\text { Grad. of shallow } \\
\text { sources }\end{array}$ & $\begin{array}{c}\text { Depth to deeper } \\
\text { sources in } \mathrm{km}\end{array}$ & $\begin{array}{l}\text { Depth to shallow } \\
\text { sources in meters }\end{array}$ \\
\hline 1 & 6.375 & 8.225 & -83.2 & -8.36 & -6.621 & -332.6 \\
\hline 2 & 6.525 & 8.225 & -67.8 & -6.9 & -5.395 & -274.5 \\
\hline 3 & 7.075 & 8.225 & -52.6 & -8.72 & -4.186 & -347.0 \\
\hline 4 & 7.225 & 8.225 & -66 & -8.9 & -5.252 & -354.1 \\
\hline 5 & 7.375 & 8.225 & -66.4 & -9.34 & -5.284 & -371.6 \\
\hline 6 & 7.52 & 8.225 & -65.4 & -8.44 & -5.204 & -335.8 \\
\hline 7 & 8.075 & 8.225 & -62.6 & -7.54 & -4.982 & -300.0 \\
\hline 8 & 8.225 & 8.225 & -74.4 & -8.84 & -5.921 & -351.7 \\
\hline 9 & 6.375 & 8.075 & -59.2 & -6.54 & -5.395 & -368.4 \\
\hline 10 & 6.525 & 8.075 & -67.8 & -4.44 & -5.828 & -238.7 \\
\hline 11 & 7.075 & 8.075 & -85.8 & -7.18 & -6.557 & -410.6 \\
\hline 12 & 7.225 & 8.075 & -82.4 & -10.38 & -6.732 & -432.9 \\
\hline 13 & 7.375 & 8.075 & -84.6 & -10.68 & -6.541 & -452.8 \\
\hline 14 & 7.52 & 8.075 & -82.2 & -8.56 & -6.462 & -293.6 \\
\hline 15 & 8.075 & 8.075 & -81.2 & -8.56 & -6.096 & -292.1 \\
\hline 16 & 8.225 & 8.075 & -76.6 & -6.8 & -5.045 & -441.7 \\
\hline 17 & 6.375 & 7.52 & -63.4 & -6.12 & -5.066 & -252.3 \\
\hline 18 & 6.525 & 7.52 & -80 & -6.3 & -6.175 & -320.7 \\
\hline 19 & 7.075 & 7.52 & -77.6 & -8.80 & -6.273 & -237.9 \\
\hline 20 & 7.225 & 7.52 & -91.4 & -8.22 & -6.369 & -309.6 \\
\hline 21 & 7.375 & 7.52 & -92.6 & -7.24 & -5.793 & -357.3 \\
\hline 22 & 7.52 & 7.52 & -72.8 & -8.68 & -6.064 & -305.6 \\
\hline 23 & 8.075 & 7.52 & -76.2 & -7.88 & -5.443 & -323.1 \\
\hline 24 & 8.225 & 7.52 & -68.4 & -8.42 & -5.100 & -188.0 \\
\hline 25 & 6.375 & 7.375 & -57.2 & -7.24 & -5.311 & -288.1 \\
\hline 26 & 6.525 & 7.375 & -59.8 & -5.7 & -5.395 & -226.8 \\
\hline 27 & 7.075 & 7.375 & -82.6 & -7.22 & -6.828 & -287.3 \\
\hline 28 & 7.225 & 7.375 & -71.8 & -7.64 & -6.557 & -304.0 \\
\hline 29 & 7.375 & 7.375 & -67.6 & -7.08 & -6.732 & -281.7 \\
\hline 30 & 7.52 & 7.375 & -74.4 & -5.64 & -6.541 & -224.5 \\
\hline 31 & 8.075 & 7.375 & -79.6 & -8.76 & -6.462 & -348.6 \\
\hline 32 & 8.225 & 7.375 & -74.2 & -8.36 & -6.096 & -332.6 \\
\hline 33 & 6.375 & 7.225 & -54 & -7.08 & -5.045 & -281.7 \\
\hline 34 & 6.525 & 7.225 & -83.6 & -9 & -6.366 & -358.1 \\
\hline 35 & 7.075 & 7.225 & -81.8 & -6.62 & -6.175 & -263.4 \\
\hline 36 & 7.225 & 7.225 & -75.6 & -6.34 & -7.273 & -252.3 \\
\hline 37 & 7.375 & 7.225 & -68.4 & -7.86 & -7.369 & -312.7 \\
\hline 38 & 7.52 & 7.225 & -90.4 & -8.04 & -6.693 & -319.9 \\
\hline 39 & 8.075 & 7.225 & -67.2 & -8.62 & -6.064 & -343.0 \\
\hline 40 & 8.225 & 7.225 & -71.4 & -8.74 & -5.443 & -347.8 \\
\hline 41 & 6.375 & 7.075 & -87.80 & -8.04 & -6.987 & -319.9 \\
\hline 42 & 6.525 & 7.075 & -98.20 & -7.42 & -7.215 & -295.2 \\
\hline 43 & 7.075 & 7.075 & 69.35 & -7.46 & -5.470 & -270.3 \\
\hline 44 & 7.225 & 7.075 & -74.60 & -6.16 & -5.936 & -245.1 \\
\hline 45 & 7.375 & 7.075 & -90.00 & -8.40 & -7.162 & -334.2 \\
\hline 46 & 7.52 & 7.075 & -89.00 & -7.14 & -7.082 & -284.1 \\
\hline 47 & 8.075 & 7.075 & -75.60 & -6.48 & -6.016 & -257.8 \\
\hline 48 & 8.225 & 7.075 & -71.20 & -8.36 & -5.666 & -332.6 \\
\hline
\end{tabular}




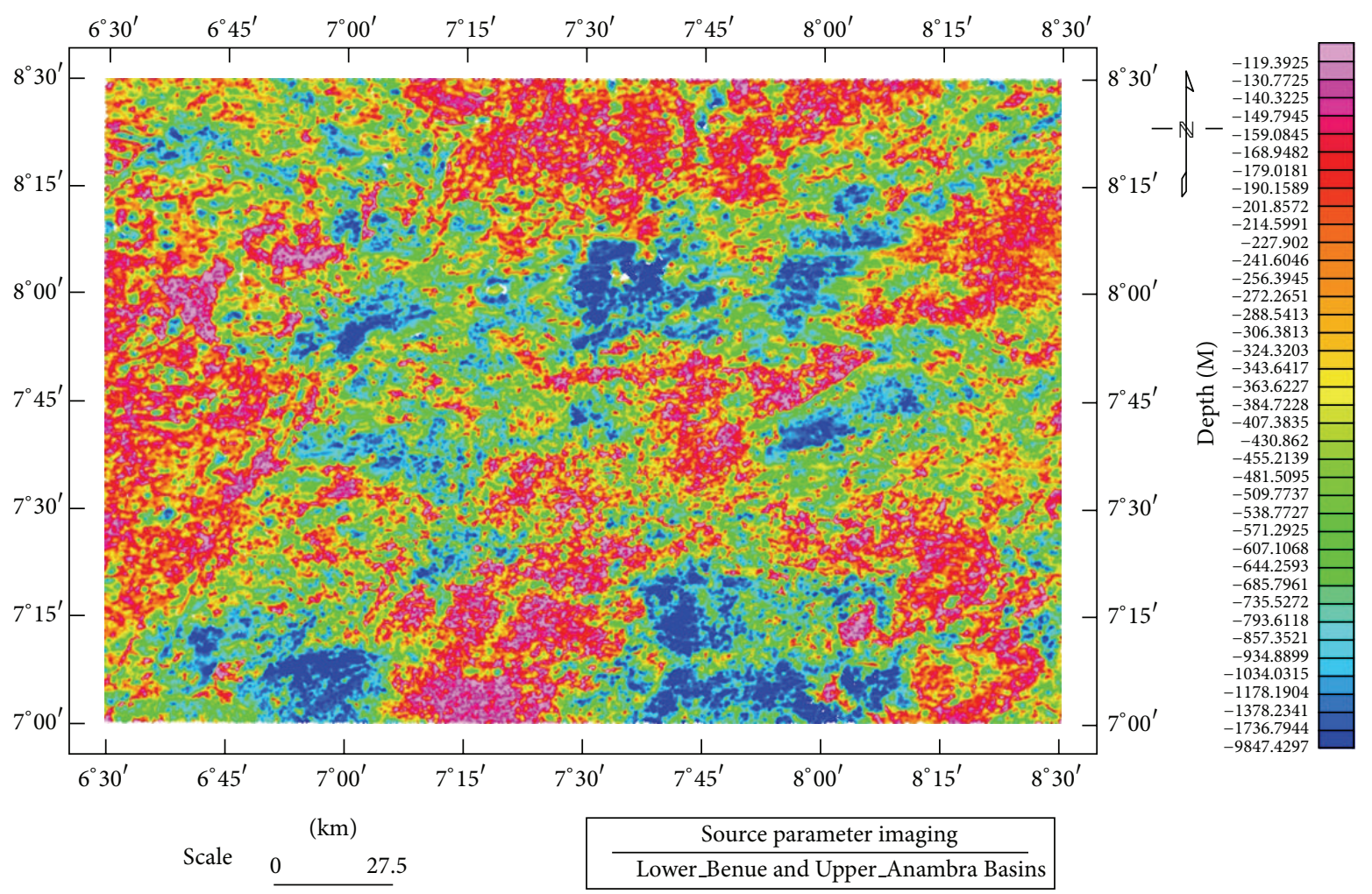

FIgURE 11: Source Parameter Imaging Depth Map of the study area.

The outcome of this research shows that the maximum depth of sedimentation within the study area is approximately $10 \mathrm{~km}$

It is understood by earth researchers that the condition for hydrocarbon generation and accumulation is guided by source rock lithology, thickness of sediments, and geothermal history. The result of depth estimates obtained by this research especially around the Anambra basin below Idah and Angba in Kogi state is of interest because it is high enough for the attainment of temperatures of approximately $60^{\circ} \mathrm{C}$ and higher than is required for thermal degradation of kerogen yielding hydrocarbons.

\section{References}

[1] C. V. Reeves, "The Kalahari Desert, central southern Africa: a case history of regional gravity and magnetic exploration," in The Utility of Gravity and Magnetic Surveys, Society of Exploration Geophysicists, Special Volume, W. J. Hinze, Ed., pp. 144-156, 1985.

[2] F. S. Grant, "Aeromagnetics, geology and ore environments, I. Magnetite in igneous, sedimentary and metamorphic rocks: an overview," Geoexploration, vol. 23, no. 3, pp. 303-333, 1985.

[3] C. V. Reeves, Aeromagnetic Surveys Principles, Practice and Interpretation, 2005.

[4] M. B. Dobrin, Introduction To Geophysical Prospecting, 2nd edition, 1960.
[5] A. Spector and F. S. Grant, "Statistical methods for interpreting aeromagnetic data," Geophysics, vol. 35, pp. 293-302, 1970.

[6] S. W. Petters, "Mid Cretaceous Paleoenvironments and biostratigraphy of the BenueTrough, Nigeria," Geological Society of America Bulletin, vol. 89, pp. 151-154, 1977.

[7] T. J. A. Reijers and C. S. Nwajide, "Geology of the Southern Anambra Basin," Field Course Note 66, Chevron Nigeria Limited, 1998.

[8] J. B. Thurston and R. S. Smith, "Automatic conversion of magnetic data to depth, dip, and susceptibility contrast using the SPI method," Geophysics, vol. 62, no. 3, pp. 807-813, 1997.

[9] B. K. Bhattacharyya, "Continuous spectrum of the total magnetic field anomaly due to a rectangular prismatic body," Geophysics, vol. 31, pp. 91-121, 1996.

[10] K. A. Ojoh, "The Southern part of the Benue Trough (Nigeria) Cretaceous stratigraphy, basin analysis, paleo-oceanography and geodynamic evolution in the equatorial domain of the south Atlantic," NAPE Bulletin, vol. 7, pp. 131-152, 1992.

[11] H. Naudy, "Method for analyzing aeromagnetic profiles," Geophysical Prospecting, vol. 18, no. 1, pp. 56-63, 1970.

[12] C. O. Ofoegbu, "A model for the tectonic evolution of the Benue Trough of Nigeria," Geologische Rundschau, vol. 73, no. 3, pp. 1007-1018, 1984.

[13] O. K. Likkason, C. O. Ajayi, E. M. Shemang, and E. F. C. Dike, "Directional filtering and spectral analysis of aeromagnetic Data over the Middle Benue Trough, Nigeria European," Journal of Scientific Research, vol. 2, no. 2, pp. 76-112, 2005. 

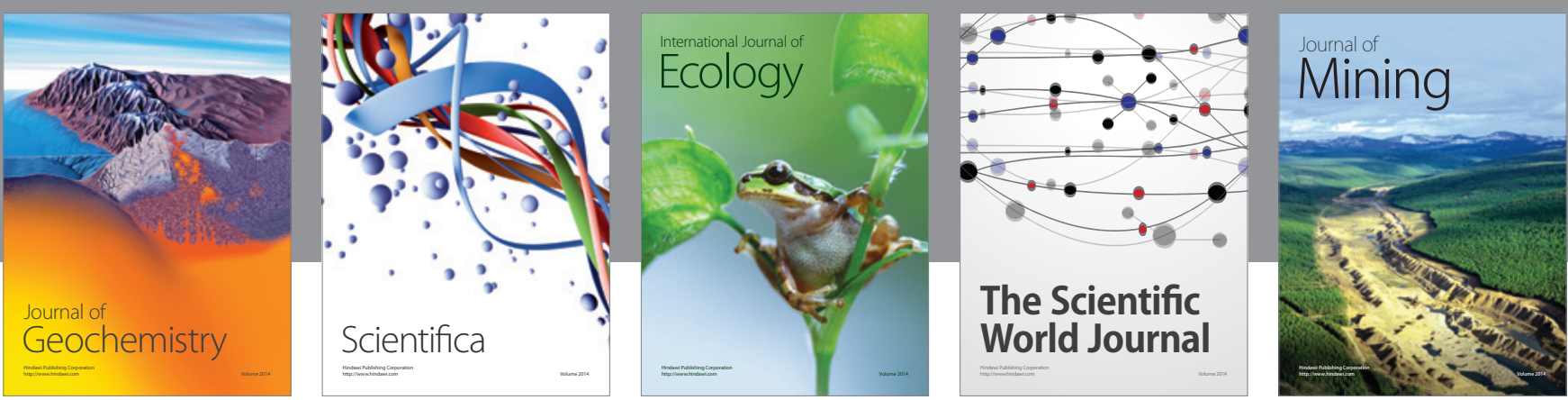

The Scientific World Journal
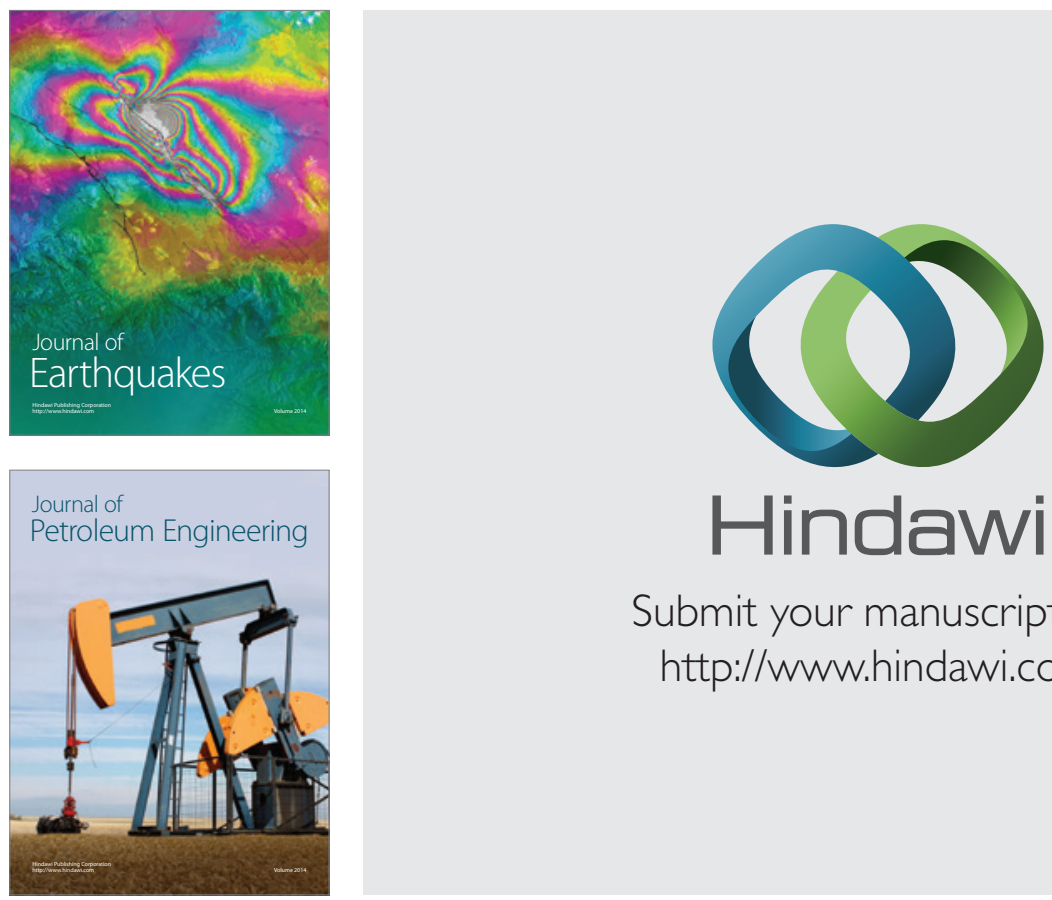

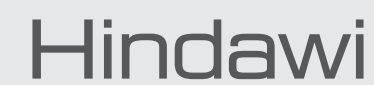

Submit your manuscripts at

http://www.hindawi.com
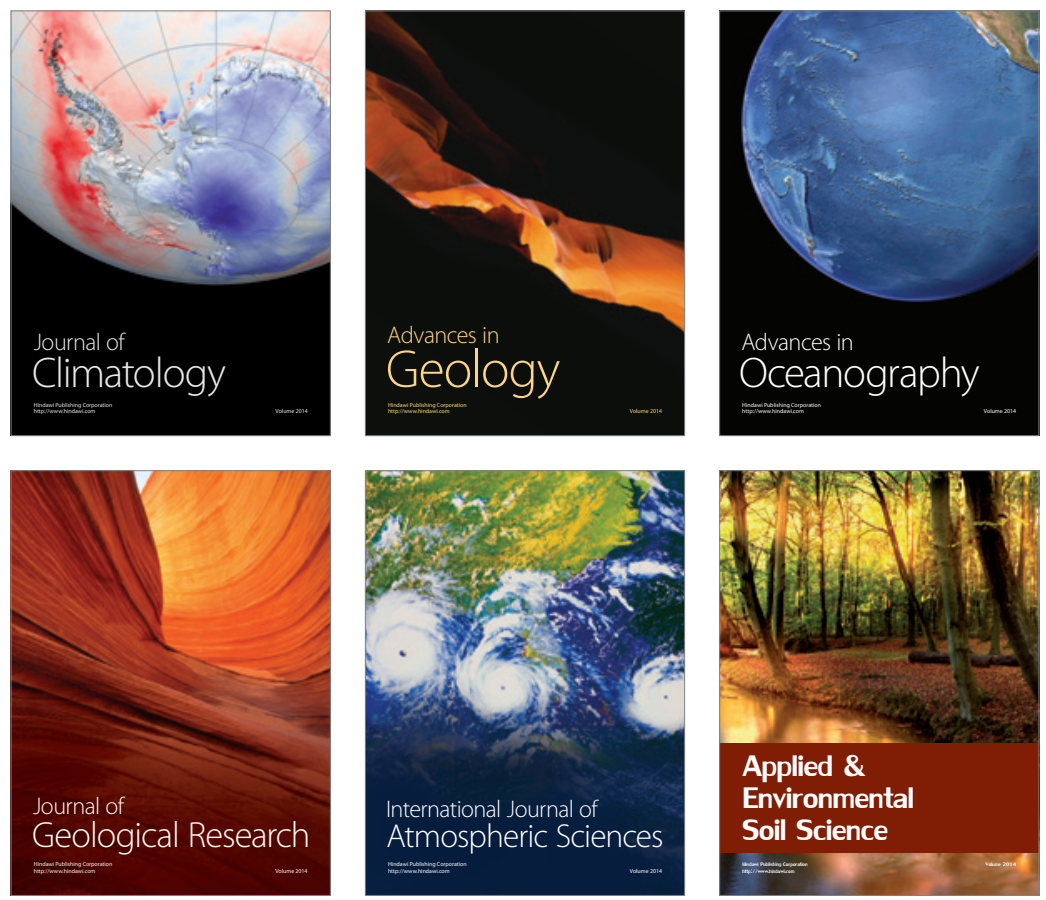
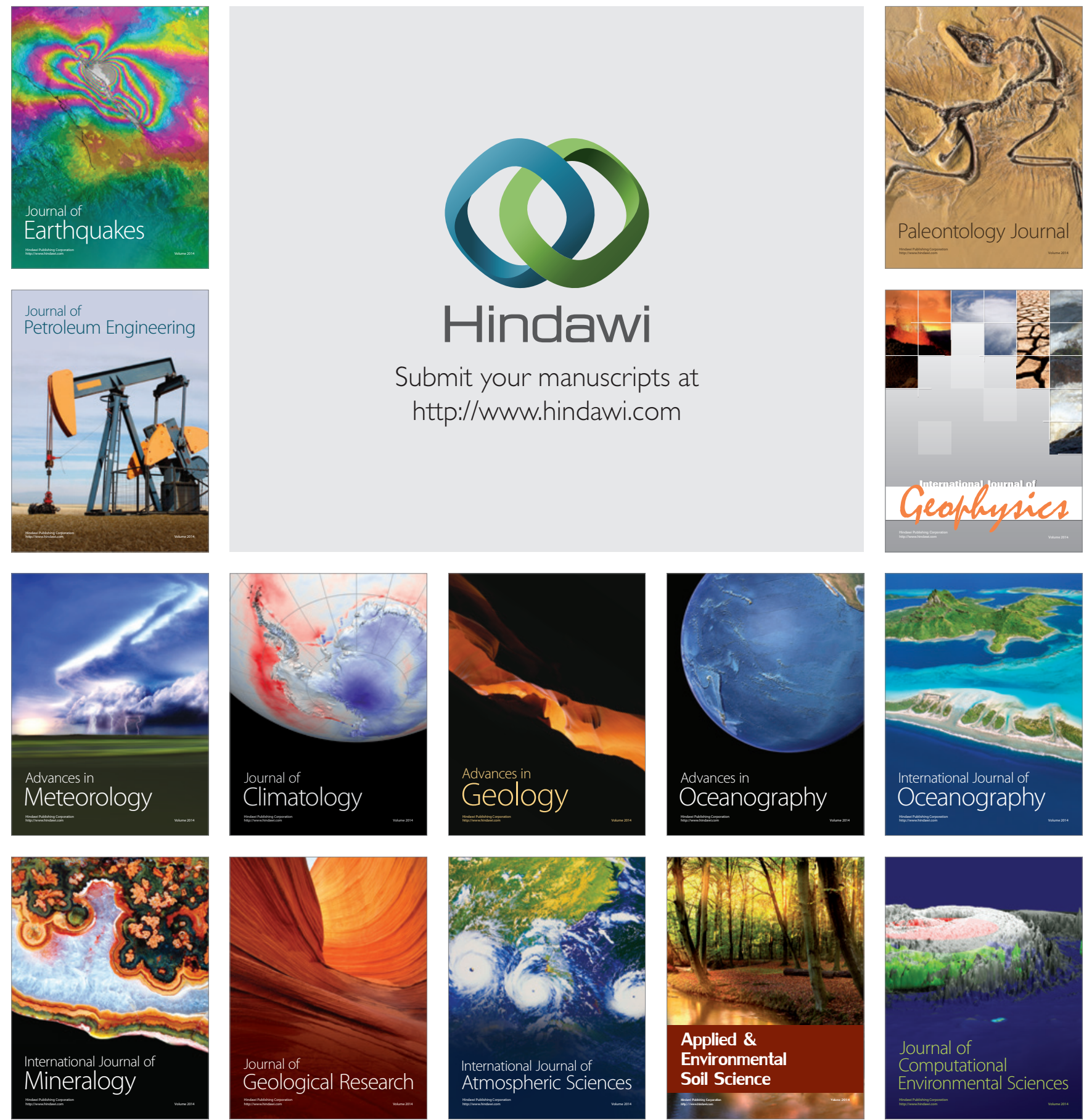